\title{
Escritas do vento sul: entrevista com Vilma Arêas
}

\author{
South wind writings: interview with Vilma Arêas \\ Elson Dias de Oliveira \\ Telma Borges da Silva \\ Universidade Estadual de Montes Claros - Unimontes - Minas Gerais - Brasil
}

$\diamond$

66 Tão se pode lê-los como romance, uma página depois da outra. Não dá. Exigem 1 a pausa, a concentração, a releitura, o convívio com o texto. Convívio lento como no amor". Tais são as palavras de Vilma Arêas acerca de sua preferência pela feitura de contos. De fato, é assim que leitor se vê diante de seus textos ficcionais. Narrativas breves, sem muitas descrições e delongas, mas que nos estremece, deixamnos suspensos, pasmos. Pedem o retorno, a procura, o comprometimento. Há que bailar no ritmo do texto, com personagens anônimos e enigmáticos. São trabalhos vagarosamente esculpidos por alguém que mora há muitos anos em São Paulo, mas que carrega dentro de si o "vento sul" fluminense (marca de sua infância em Campos dos Goytacazes e que está presente em muitas narrativas).

Pesquisadora-ensaísta e contista-ficcionista, Vilma plasma tanto a "matéria crítica" quanto a "matéria ficcional". No universo literário, estreou com Partidas (1976). Aos trancos e relâmpagos (Scipione, 1988) e A terceira perna (Brasiliense, 1992) foram agraciados com o prêmio Jabuti. Na sequência, lançou Trouxa frouxa (Cia das Letras, 2000) e Vento Sul (Cia das Letras, 2011); tendo este último conquistado o prêmio Alejandro José Cabassa, da União Brasileira de Escritores. Já no cenário crítico, o perspicaz Clarice Lispector com a ponta dos dedos (Cia das Letras, 2005) também recebeu o Jabuti, além do prêmio APCA (Associação Paulista de Críticos de Arte). Tem vários outros trabalhos críticos, resultantes de sua notável carreira acadêmica na PUC-Rio, na USP, UFF e na Unicamp; nesta última como professora titular do Departamento de Teoria Literária. É constitutivo de sua ficção e de sua ensaística o trabalho com a crise das relações humanas no contexto citadino contemporâneo (contradições e contravenções familiares, preconceito e subalternidade, violência e marginalização, etc.).

Nesta entrevista, gentilmente concedida em maio de 2016, Vilma nos brinda com opiniões e confissões de sua trajetória como escritora e crítica. Com galhardia e, ao mesmo tempo, com um humor simples e cativante, ela nos diz de seu primeiro encantamento pela escrita, de suas memórias e preferências, de sua linguagem ficcional, de alguns contos especificamente, de sua aversão aos rótulos que circundam os estudos literários, e questões outras. Aqui, Vilma também é sem rodeios, constrói frases curtas, mas o faz com enlevo e bom humor. Na conversa que se segue, encontrar-se-á um sentimento poético extraordinário. 
- Para início de conversa, permita-me indagar sobre o modo como a literatura aconteceu na sua vida. Digo: a gênese, a formação daquela que viria a ser a escritora e pesquisadora Vilma Arêas. Houve algum acontecimento propedêutico marcante?

- Sempre gostei de fazer redações no primário. Uma por dia. A professora corrigia com uma canetinha vermelha, mandava copiar sem os erros e devolver. Depois comecei a inventar, era uma espécie de brinquedo. Desenhava bonecos, recortava-os e compunha histórias. Os perversos eram picados com a tesourinha. Depois que li a história da Joana D'Arc, acendia uma vela e... fim com eles. Os outros eram guardados numa grande caixa. Um dia vim correndo do colégio, louca para brincar, abri a caixa tinha 11 anos - e não achei nenhuma graça. Fiquei com uma pedra no peito. Aí escrevi um texto no meu caderno: "o túmulo de uma ilusão". Uma tia leu e adorou, guardou com ela. Acho que foi assim que começou. Comecei a escrever outros túmulos.

- Desde o início dos estudos literários, há escritorescríticos, num duplo movimento de fazer literatura e fazer crítica literária. É o seu caso, Vilma. E o faz magnificamente. Como é jogar esse jogo, sem deixar um habitual rigor metodológico e sistemático artificializar a ficção?

- A ficção para mim sempre foi um espaço de liberdade e gratuidade. Nunca pensei em ganhar dinheiro escrevendo, talvez não saiba, não se trata de santidade. Quanto à crítica, trata-se de uma profissão, consequência do magistério.

Tens uma atenção especial com autores, obras e temáticas da literatura brasileira contemporânea. Inclusive, orientaste alguns trabalhos sobre a prosa de Campos de Carvalho; além de ter escrito sobre ele na Folha de São Paulo (1995). Gostaria que dissesse algumas palavras sobre a "arte bruta" desse autor, expressão cunhada por você mesma.

- Não, a expressão é de Dubuffet, referindo-se à arte dos alienados e, como afirmei, Vaca de nariz sutil admite certa dívida em relação a essa arte. Mas é charme do autor. $\mathrm{O}$ Noel Arantes, que elaborou uma bela tese sobre Campos de Carvalho, poderá esclarecer melhor essa observação. Campos de Carvalho é um escritor bem especial, um sarcástico de alto lirismo, que merece ser melhor lido nos dias de hoje.

- Comente um pouco sobre a sua percepção da literatura brasileira contemporânea; conjuntura e (des)rumos. Que avaliação você faz?

- Como sempre, há bons escritores, profissionais ou não, e outros nem tão bons assim. Mas o que atrapalha é que o desenvolvimento nunca visto do capitalismo transforma tudo em mercadoria. Não é que não tenha havido mercado antes, mas hoje, ou você se vende na praça, ou nada feito. Essa enxurrada asfixia a respiração dos bons livros.

- Você nos deixou um perspicaz estudo intitulado Clarice Lispector com a ponta dos dedos (2005). Vê-se a defesa de um ordenamento dialético dos escritos de Clarice, demonstrando a profundidade daquela parte (tardia) tomada como dessintonizada das obras urdidas "com as entranhas". Tendo em vista esse interesse pela literatura de Clarice, diga-nos se há, em seus trabalhos ficcionais, fios em comum com o "bordado" clariceano.

- Acho que não. Tenho até um conto sobre ela, escrito com palavras dela ao redor dos diálogos que mantivemos. Ela havia morrido e é uma espécie de texto ditado pela saudade.

Por falar em fios em comum, eu já li em algum lugar que você é admiradora confessa de uma das maiores escritoras italianas do séc. XX: Natalia Ginzburg. Poderia descrever, para nós, o que mais se vos apresenta como exímio nessa tessitura além-mar? Como você descobriu a literatura da Natalia?

- Minha família, como a maioria das famílias no Brasil, descende de africanos, portugueses e italianos, entre outras raças. Tenho uma irmã mulata, caboclos na família e gente muito clara. Tudo isso - ando irritada com o preconceito de hoje - para dizer que a literatura italiana sempre me interessou. Quando li Lessico Famigliare caí para trás. Mas escrevi um longo posfácio para Caro Michele, um livro que sempre releio, traduzido pela Cosac. Lá explico o que penso da Natalia.

Atendo-nos, de agora em diante, à sua criação literária, há um ponto constitutivo que você poderia comentar: o ultraje à divisão formal de gêneros literários. São contos, narrativas breves, ficções, etc. Não há limites estruturais para prosa de Vilma Arêas. O prefácio de Partidas (1976) revela isso, sobremaneira. Como você pensa essa insubmissão aos gêneros?

- Acho que escrevo coisas curtas, porque acho que não é necessário escrever muito, ainda mais diante do romance do século XIX. Mas isso é uma explicação que não convence. Na verdade tenho uma novelinha chamada Aos trancos e relâmpagos, embora alguns capítulos possam ser lidos separadamente. Por sua vez, os livros de textos curtos possuem um fio subterrâneo que surge aqui e ali. Acho que a grande voz de uma época é a poesia. Por isso tenho medo de escrever poesia. Às vezes acho que 
chego perto, como o penúltimo texto de Trouxa frouxa. O problema da poesia ou dos textos curtos - sempre digo aos alunos - é que eles exigem leitura lenta. Não se pode lê-los como romance, uma página depois da outra. Não dá. Exigem a pausa, a concentração, a releitura, o convívio com o texto. Convívio lento como no amor. Slow reading, não fast reading. Os apressados ou as apressadas perdem o melhor com a correria. Comem cru, não é o que dizem?

Algo, também, que contraria as formas tradicionais diz respeito ao cruzamento de vozes (narrador e personagens) no interior de algumas narrativas. Pude perceber isso em contos de A terceira Perna (1992) e Vento Sul (2011). Por que essa sobreposição de vozes?

จ Isso não é novo, é muito antigo. O Brecht foi um grande teórico dessa quebra de ilusão. Eu escrevo, falo de outra pessoa, mas sou eu, mas não sou eu. Enfim...

- Por trás de uma sintaxe enxuta, de uma linguagem concisa, aparentemente simples, há em teus textos uma complexidade e agudeza ímpar, obrigando o leitor a cooperar ativamente com os "vestígios". Por que exigir tanto do leitor?

- Que delícia, você notou perfeitamente o que quero fazer: obrigar o leitor a cooperar, a montar também a escrita. Afinal o leitor, acho, é pessoa inteligente, pode ser explorado. Não acha?

- O conto "À queima-roupa" descerra-nos três dimensões: o sonho dentro do sonho; o próprio sonho; e a realidade "desperta". Em "No fundo do rubi" você coloca a ficção dentro da ficção, entrecruza a "vida" e o "palco". Fiquei impressionado. Há algum trabalho ou autor que inspira tais efeitos? Não reconhece uma ponta de surrealismo em alguns de seus contos?

- Tem razão. O primeiro é um sonho dentro de um sonho. Até o Martinho da Vila fez isso e me deu coragem. Mas "No fundo do rubi" pretendi que fosse bem realista. Tudo aconteceu assim: eu estava com um namorado que saiu para comprar cigarros. Demorou bastante e quando voltou me contou toda aquela história. Verdade ou mentira? Não me interessei por isso, achei a história bárbara, bem no feitio dele, que era um homem completamente especial. Gostei muito da frase do gordo, com o anel de rubi, perguntando se ele ia pagar toda santa noite para a mendiga dormir no quente. $\mathrm{O}$ que desmonta inteiramente a bondade da esmola dada aos pobres, não é? Ele também ficou arrasado com isso. Enfim, ilusões da pequena burguesia, escritas como comédia.
- No que concerne ao material da composição, você é daquele tipo perseguido por temas e assuntos? Quer dizer: que só tranquiliza o "gênio perseguidor" quando transforma aqueles "ingredientes básicos" numa tessitura ficcional.

○ Às vezes sou, sim, perseguida por um assunto. Insisto, insisto, mas se não consigo, deixo pra lá. Um belo dia, às vezes surge a solução. O último conto do Vento Sul levou anos para ser resolvido. Eu já tinha desistido, quando comecei a reler uma madrugada o excelente Trabalho de Brecht do José Antônio Pasta. Então levantei, peguei meu texto e resolvi. Quer dizer, acho que resolvi. Essas coisas são engraçadas. Ele disse que entendeu tudo. Eu, não, mas não perguntei.

- Há muito de sua infância, adolescência e juventude fluminense nas narrativas? $E$ das viagens Brasil a fora? Suas idas a Portugal, à Espanha, aos Estados Unidos, etc., permitiu alguma matéria narrável?

- Ah, sim, claro, acho que a gente escreve muito com o corpo, há sempre um "resto" material nessas contas e nesses contos.

Você constrói personagens mulheres transgressoras, ferinas, protagonistas. Numa época em que se avultam as expressões "literatura feminina", "literatura feminista", "literatura escrita por mulheres", etc., como você se situa perante tais abordagens de gênero?

- Mas as feministas não são transgressoras de uma certa moral, não são protagonistas? Sou feminista e de esquerda, mas não cubro a literatura com esses rótulos. Entretanto acho que as coisas aparecem. É só ler o que está lá.

Muitos de seus narradores não se preocupam em descortinar o passado dos personagens. Estes são lançados em cena; desterritorializados, anônimos. É próprio das narrativas curtas ou uma ferramenta estético-literária de que fazes questão de se servir?

○ É, você tem razão. Não me preocupo muito com o enredo. Aliás eles me entediam um pouco. Por isso prefiro a poesia não narrativa, que sempre é também um pouco narrativa.

Encaminhando-nos para os remates, permita-me fazer alguns questionamentos um tanto inespecíficos, mas bastante pessoais: Por que narrar? Por que transmutar o real para o ficcional?

- Gosto muito da grande poeta Wislawa Szymborska, se não conhece, leia imediatamente; perguntada o que era a 
poesia, diz "o que é isso poesia? Não sei, não sei e não sei".

- Num cenário de grande circulação de livros (muitos feitos às pressas e pouco edificantes), percebe-se que não publicas com frequência. Acho que distingue muito bem o "fazer" literatura do "fabricar" literatura.

- Escrevo todos os dias, mas não publico porque acho que os textos não valem a pena, porque é este o meu processo de escrever. Não preciso publicar, não vivo disto para comer ou morar. É ótimo isso. Casamento por amor. Eu, você e o mar batendo na praia. Sei que é romantismo, mas deixe pra lá.

\section{- Por fim, há algum trabalho (crítico ou ficcional) em} mente ou prestes a ser lançado?

$\rightarrow$ Tenho sim, alguns até prontos. Mas não estão ainda prontos. Pode acreditar em mim.
Uma porta batia sem descanso. Acordou então dentro do sonho, pois sonhava que dormia. A porta que batia levava à varanda envidraçada à beira do jardim. Levantou-se na escuridão para fechá-la, não precisava de luz. Mas quando tropeçou e caiu despertou daquele outro despertar que era ainda sonho. A porta batia, batia agora longe, no fundo de um corredor atulhado de livros. Pressionado, o trinco fez um estalido que se confundiu com o tiro à queima-roupa de alguém que exclamara ah! ao ser surpreendido. Tombou em câmara lenta, mas antes de mergulhar de novo numa inconsciência molhada e macia, por segundos voltou a sentir aquele cheiro de treva e humidade, enquanto o intruso meticulosamente virava seu corpo inerte para a janela de onde se via a mulher de pedra deitava nas montanhas, esculpida no ar. (Trecho do conto “À queima-roupa”, presente em Vento Sul. São Paulo: Companhia das Letras, 2011).

Recebido: 03/12/16

Aprovado: 09/03/17

Contato: elsonrpm@yahoo.com.br t21m1b3rg2s@yahoo.com 